\title{
MENINGKATKAN KETERAMPILAN SISWA TUNARUNGU DALAM MENULIS KARANGAN SEDERHANA MELALUI MEDIA GAMBAR BERSERI DI KELAS DIV-B SLB-E NEGERI PEMBINA MEDAN
}

\author{
Sitti Nurliani Tarigan
}

Surel : sittinurliani@yahoo.com

\begin{abstract}
ABSTRAK
Penelitian tindakan kelas ini bertujuan untuk meningkatkan keterampilan siswa tunarungu dalam menulis karangan sederhana melalui media gambar berseri di kelas DIV-B SLB-E Negeri Pembina Medan. Subjek dalam penelitian tindakan kelas ini adalah siswa tunarungu kelas DIV-B SLB-E Negeri Pembina Medan yang berjumlah 6 orang yang terdiri dari 4 siswa perempuan dan 2 siswa laki-laki. Teknik pengumpulan data yang digunakan dalam penelitian ini adalah dengan menggunakan data kuantitatif berupa test dan data kualitatif berupa observasi. Hasil observasi menunjukkan bahwa pada siklus I guru (peneliti) sudah dapat meningkatkan keterampilan siswa tunarungu kelas DIV-B SLB-E Negeri Pembina Medan dalam menulis karangan sederhana dengan menggunakan media gambar berseri dengan baik dan pada siklus II guru (peneliti) dapat meningkatkan kemampuan siswa tunarungu dengan lebih baik dengan menggunakan media gambar berseri dalam menulis karangan sederhana dalam pembelajaran B.Indonesia.
\end{abstract}

Kata Kunci : Siswa Tunagrungu, Menulis Karangan Sederhana, Gambar Berseri.

\section{PENDAHULUAN}

Berbagai sumber dan pengalaman dapat dijadikan bahan untuk dituangkan dalam bentuk tulisan. Dalam kegiatan menulis, seorang siswa tunarungu tidak harus menulis sesuatu yang belum pernah ada, tetapi ia dapat menulis berbagai hal, memodifikasi tulisan yang dibaca, membuat versi lain dari sebuah tulisan, bahkan dapat mengkonstruksi berbagai tulisan ke dalam sebuah tulisan atau memecah sebuah tulisan ke dalam beberapa tulisan. Intinya, seorang siswa tunarungu harus memanfaatkan berbagai hal dalam proses kreativitas menulis.

Dalam konteks kreativitas menulis di atas, siswa tunarungu harus memiliki kesadaran yang tinggi dan mengerti apa yang akan ia tulis. Bagi Piaget (dalam Gani, 2000:2), mengerti adalah suatu proses adaptasi intelektual dengan pengalaman-pengalaman dan ide-ide baru diinteraksikan dengan apa yang sudah diketahui oleh seseorang yang sedang belajar untuk membentuk struktur pengertian baru. Ia menambahkan bahwa dalam pikiran seseorang ada struktur pengetahuan awal (skema). Setiap skema berperan sebagai suatu filter dan fasilitator bagi ide-ide dan pengalamanpengalaman yang baru. Skemata mengatur, mengkoordinasi, dan mengintensifkan prinsip-prinsip dasar. Melalui kontak dengan pengalaman baru, skema dapat dikembangkan dan diubah, yaitu dengan proses asimilasi dan akomodasi Salah satu wujud dari kontak pengalaman baru di atas adalah adanya kontak antara siswa dengan guru. Kontak tersebut berupa interaksi kondusif yang dibangun secara bersama-sama. Menurut pandangan kaum konstruktivistik, kegiatan memindahkan pengetahuan 

dari guru kepada siswa. Dalam konteks ini, kegiatan guru memungkinkan siswa membangun sendiri pengetahuannya. Guru berpartisipasi dalam proses pembelajaran dengan membentuk pengetahuan, membuat makna, mencari kejelasan, bersikap kritis, dan mengadakan justifikasi (Bettencourt dalam Suparno, 1997:17).

Salah satu upaya untuk mewujudkan tujuan dari pendidikan adalah dengan melalui Pembelajaran Bahasa Indonesia di SLB-B. Adapun empat keterampilan yang harus dikuasai oleh siswa tunarungu dalam pembelajaran Bahasa Indonesia yaitu: keterampilan membaca, keterampilan menulis, keterampilan menyimak dan mengarang sederhana.

Penguasaan keterampilan menulis karangan tidak diperoleh secara spontan atau alamiah akan tetapi membutuhkan latihan yang intensif dan memerlukan tahap-tahap pembelajaran yang membutuhkan waktu yang tidak sedikit serta membutuhkan proses yang cukup lama. Proses berlatih menulis karangan tersebut dapat dilakukan oleh siswa tunarungu secara formal melalui pembelajaran Bahasa Indonesia yang dimulai sejak dini.

Berdasarkan kenyataan bahwa menulis karangan tidak diperoleh secara spontan, maka peneliti melakukan observasi langsung di tempat penulis mengajar tepatnya di kelas D-IV-B SLB-E Negeri Pembina Medan pada hari sabtu tanggal 30 Agustus 2016, dengan hasil observasi pada umumnya siswa tunarungu di kelas D-IV-B kurang terampil dalam menulis karangan sederhana pada pembelajaran Bahasa Indonesia karena siswa tunarungu kurang mampu dalam memilih kata dalam menuangkan buah pikirnya, di samping itu siswa tunarungu yang mengikuti pelajaran kurang bersemangat karena media tidak menarik minat siswa dalam proses belajar mengajar, sehingga siswa kurang aktif dalam pembelajaran menulis. Kalimat yang satu dengan yang lainnya tidak tersambung, paragraf yang satu dengan yang lainnya tidak koheren. Dari hasil observasi, guru kurang menggunakan media yang sifatnya kreatif dan inovatif dalam proses belajar mengajar yang melibatkan aktivitas mental, fisik dan emosional.

Selain hal tersebut di atas, peneliti juga menemukan bahwa nilai rata-rata siswa dalam pembelajaran Bahasa Indonesia, khususnya dalam menulis karangan pada siswa tunarungu kelas D-IV-B SLB-E Negeri Pembina Medan yang berjumlah 5 orang nilainya belum mencapai KKM yaitu masih 50 yang seharusnya nilai rata-rata yang menjadi kriteria ketuntasan minimal (KKM) adalah 60. Alasan dari perolehan nilai tersebut adalah bahwa pembelajaran menulis karangan sederhana kurang mengaktifkan siswa dalam proses belajar mengajar sehingga berakibat pada rendahnya nilai B.Indonesia 
pada siswa tunarungu kelas D-IV-B SLB Negeri Pembina Medan.

Keterampilan menulis karangan berbeda dengan jenis keterampilan berbahasa lainnya karena keterampilan menulis karangan merupakan kegiatan berkomunikasi dengan menggunakan bahasa tulis sebagai medianya. Sejalan dengan itu, Abidin (2012: 181) menyatakan bahwa menulis karangan pada dasarnya adalah proses untuk mengemukakan ide dan gagasan dalam bahasa tulis. Menulis karangan merupakan salah satu hal yang perlu dimiliki oleh siswa tunarungu di mana kita ketahui bahwa siswa tunarungu yang kita harapakan sekali adalah perkambangan bahasanya di samping meningkatkan bicaranya juga menulis, terutama pada siswa kelas awal, yaitu siswa kelas I sampai dengan kelas IV. Oleh sebab itu, Akhadiah (Abidin 2012: 181) memandang bahwa "Menulis adalah sebuah proses, yaitu proses penuangan gagasan atau ide ke dalam bahasa tulis, yang dalam praktiknya proses menulis diwujudkan dalam beberapa tahapan yang merupakan satu sistem yang utuh". Dengan memiliki kemampuan menulis, siswa dapat mengkomunikasikan ide, dan pengalamannya ke berbagai pihak. Lebih lanjut Gie (Abidin 2012: 181) menyatakan bahwa "Menulis memiliki kesamaan makna dengan mengarang, yaitu segenap kegiatan seseorang mengungkapkan gagasan dan menyampaikannya melalui bahasa tulis kepada pembaca untuk dipahami".

Sejalan dengan pendapat diatas, maka menulis adalah kegiatan yang dilakukan oleh seseorang guna menuangkan gagasan ataupun pengalamannya dalam bentuk tulisan untuk disampaikan kepada pembaca, atau dengan kata lain menulis adalah alat komunikasi non verbal.

Keterampilan menulis sebagai salah satu cara dari empat keterampilan berbahasa, mempunyai peran yang penting di dalam kehidupan manusia. Menulis karangan pada prinsipnya adalah bercerita tentang sesuatu yang ada dalam imajinasi seseorang. Penceritaan tersebut dapat dituangkan dalam bentuk lisan maupun tulisan.

Agar pembelajaran menulis karangan dapat terlaksana dengan baik pada siswa tunarungu kelas DIV-B SLB Negeri Pembina Medan, diperlukan guru yang terampil untuk merancang dan mengelolah pembelajaran. Salah satu upaya yang dapat penulis lakukan dalam proses pembelajaran agar siswa lebih aktif dan kreatif dalam pembelajaran Bahasa Indonesia khususnya dalam meningkatkan keterampilan menulis karangan yaitu dengan menggunakan media gambar berseri.

Sebagaimana diketahui gambar berseri mempunyai peranan yang cukup pentig dalam membantu siswa meningkatkan keterampilan menulis karangan, karena dengan menggunakan media gambar berseri, siswa dapat melihat hubungan antara 
konsep, peristiwa, dan tokoh yang ada dalam pelajaran serta siswa dapat melihat hubungan antara komponenkomponen materi atau isi pelajaran yang diajarkan. Dengan bantuan media gambar berseri, guru akan lebih mudah mengatasi gangguan yang akan menghambat proses pembelajaran dan mengambil alih perhatian siswa.

adalah untuk "Meningkatkan keterampilan siswa tunarungu dalam menulis karangan sederhana melalui media gambar berseri pada kelas DIV-B SLB-E Negeri Pembina Medan Tahun Pelajaran 2016/2017”.

\section{METODE PENELITIAN}

Penulisan yang dilakukan penulis adalah merupakan penulisan tindakan kelas (class room action research). Subjek penelitian adalah siswa kelas D-IV-B SLB-E Negeri Pembina Medan semester Iyang berjumlah 5 orang terdiri dari 3 orang perempuan 2 orang laki-laki. Model PTK yang digunakan, kolaborasi, maksudnya; guru berkolaborasi dengan guru yang mengajar di SLB-E Negeri Pembina Medan dalam hal ini adalah ibu Purwanti S.Pd.Tempat penelitian dilakukan di SLB-E Negeri Pembina Medan.Penelitian ini di lakukan selama 4 bulan (Agustus November)semester I (ganjil) tahun pelajaran 2016/2017 dengan menggunakan acuan Kurikulum Tingkat Satuan Pendidikan SDLB-B berdasarkan Standar Satuan Pendidikan
Nasional. Pelaksanaan penelitian dilakukan setiap hari selasa pada pembelajaran B.Indonesia.

Sumber data dari penelitian ini berasal dari siswa kelas D-IV-B SLB-E Negeri Pembina Medan, kepala sekolah, guru kelas yang relevan, guru olah raga dan guru yang mengajar di SLB-E Negeri Pembina Medan. Teknik pengumpulan data dalam jenis penelitian ini menggunakan teknik Observasi, dan wawancara.

Obsevasi di lakukan untuk mengoptimalkan kemampuan peneliti dari segi motif, kepercayaan, perhatian, prilaku tak sadar, kebiasaan dan sebagainya. Observasi memungkinkan peneliti untuk melihat dunia sebagai mana dilihat oleh responden penelitian, bagaimana ia melakukan dan mengapa ia melakukan sesuatu.

Wawancara dalam penelitian ini dilakukan karena peneliti bermaksud menambah dan melengkapi data serta mencocokkan pengetahuan siswa sehari-hari yang diteliti dan diamati dengan keterangan orang tua yang ketika di wawancarai tentang pengetahuan menulis karangan sederhana yang sudah bisa dilakukan siswa seharihari atau di rumah dengan penegatahuan yang di dapat dari sekolah. Hal ini kadang informasi orang tua kadang tidak sesuai dengan keadaan yang sebenarnya, ini menjadi penting untuk dipergunakan sebagai dasar untuk meningkatkan pengetahuan siswa kearah yang lebih 
baik sesuai dengan yang diharapkan. Wawancara dilakukan selain dengan orang tua juga dilakukan dengan guru kelas yang relevan, hal ini untuk memperoleh imformasi yang lebih kaya dan beragam mengenai keadaan sabjek penelitian. Untuk memudahkan pengumpulan data, peneliti membutuhkan alat bantu agar penelitian aptudate dan berkualitas dari hasil penelitiannya. Kamera dalam penelitian ini dipergunakan untuk mengambil gambar atau peristiwa-peristiwa yang berhubungan dengan penelitian yang akan disertakan sebagai data resmi penelitian berupa gambar-gambar yang sengaja diambil ketika siswa diberi perlakuan dalam meningkatkan keterampilan menulis karangan sederhanayang diberikan oleh peneliti saat pembelajaran sedang berlangsung di dalam kelas.

Penelitian tindakan kelas ini menggunakan analisis rata-rata skor dan persentase. Kegiatan analisis data ini dilakukan untuk menganalisis proses dan hasil belajar siswa pada saat pembelajaran berlangsungberdasarkan lembar penilaian pada kemampuan siswapada di kelas DIV-B SLB-E Negeri Pembina Medan. Data tes dianalisis dengan menggunakan nilai rata-rata individu siswa, dan kriteria ketuntasan belajar siswa.

a. Nilai rata-rata

Nilai akhir rata-rata siswa dihitung dengan menggunakan rumus :

$$
\bar{x}=\frac{\sum X}{N}
$$

Keterangan :

$\bar{x}=$ Nilai Akhir Rata-rata anak

$\Sigma \mathrm{X}=$ Jumlah Nilai akhir anak

$\mathrm{N}=$ Jumlah anak

(Suharsimi, 2002 :264)

b. Persentase ketuntasan belajar secara klasikal atau perorangan

Ketuntasan belajar secara klasikal dihitung dengan menggunakan rumus :

$$
P=\frac{n}{N} x 100 \%
$$

(Suharsimi, 1987)

Keterangan :

$\mathrm{P}=$ Tingkat Kemampuan

$\mathrm{N} \quad=$ Jumlah nilai anak yang diperoleh dari data

$\mathrm{N} \quad=$ Jumlah anak

$100 \%=$ Nilai Konstan

Pada tahap perencanaan ini peneliti menentukan langkahlangkah pengembangan seperti : (1) Bekerjasama bersama kolaborator menetapkan urutan materi pembelajaran dan cakupannya, (2) Membuat RPP, (3) Menyiapakan media pembelajaran, (4) Menyiapkan lembar observasi, (5) Mendesain alat evaluasi yang sesuai dengan tujuan pembelajaran.

Pada tahap pelaksanaan tindakan ini, guru melaksanakan kegiatan pembelajaran sesuai dengan yang telah direncanakan. Guru melaksanakan kegiatan pembelajaran menulis karangan sederhana dengan menggunakan gambar berseri

Pembukaan : 
Sementara kegiatan pembelajaran berlangsung obsever atau kolaborasi mengamati pelaksanaan kegiatan menulis karangan sederhana dengan indikator yang di harapakan. Hal yang diamati yaitu semua prilaku (kemampuan) anak dalam mengikuti kegiatan. Setelah mengamati pada kegiatan akhir/penutup dilakukan kemampuan siswa dinilai dalam bentuk $\%$.

Setelah data observasi dianalisis, guru melakukan refleksiterhadap kegiatan pembelajaran yang telah dilaksanakan. Pada tahap ini, tim observer dan guru berusaha untuk dapat mengetahui kemampuan siswa dalam pembelajaran yang telah dilakukan. Hasil tersebut digunakan untuk menentukan tindakan pada siklus berikutnya.

$\begin{array}{ccc} & \text { Adapun langkah-langkah } \\ \text { dalam refleksi tindakan yaitu }\end{array}$ diantaranya langkah pertama merinci dan menganalisis efektifitas pembelajaran yang didasarkan pada hasil diskusi antara tim observer terhadap hasil observasi aktifitas siswa, data hasil observasi guru, serta hambatan yang dihadapi guru, minat/ ketertarikan belajar dalam belajar menulis karangan sederhana. Langkah kedua mengidentifikasi permasalahan yang sudah dan belum terpecahkan atau yang muncul selama pembelajaran berlangsung, dengan mengajukan mengisi skor tuntas dan belum tuntas jika siswa sudah menunjukan nilai sesui KKM yang diharapakan yaitu nilai siswa 60.
Pelaksanaan siklus II
dilakukan pemahaman media pembelajaran yaitu menggunakan media gambar berseri untuk membuat karangan sederhana. Langkah-langkah yang akan dilakukan pada siklus II :

Diskusi dengan peneliti dan teman sejawat tentang permasalahan baru yang timbul pada siklus I, hasil refleksi pada siklus I dijadikan dasar menyusun rencana perbaikan pembelajaran RPP pada siklus II

Pada tahap pelaksanaan tindakan, guru melaksanakan kegiatan pembelajaran sesuai dengan yang telah direncanakan. Guru memberikan beberapa gambar berseri kepada siswa kemudian siswa disuruh menyusunnya sesuai urutan gamabr dan siswa disuruh menulis karangan sederhana sesuai gambar berseri yang di bagikan. Guru membimbing dengan menggunakan bahasa isyarat agar siswa lebih memahami lagi bagai mana cara menulis karangan yang baiak.

Penilaian yang diobservasi adalah tentang keterampilansiswa menulis karangan sederhana. Pada penilaian ini dilihat perubahan yang terjadi pada siswa saat siklus I dan pada siklus II. Cara penilaian berdasarkan kemampuan siswa masing-masing pada siklus I dan ke II bukan pada kemampuan kelompoknya.

Setelah data observasi dianalisis, guru melakukan refleksi diri terhadap kegiatan pembelajaran yang telah dilaksanakan. Pada tahap ini, tim observer dan guru berusaha 
untuk dapat mengetahui kemampuan siswa dalam pembelajaran yang telah dilakukan pada siklus II

Indikator kinerja yang dijadikan tolok ukur dalam penelitian ini antara lain, yaitu dengan penilaian yang dilakukan atas dasar tes. Siswa dinyatakan berhasil jika nilai penguasaan menulis karangan sederhana yang diperoleh sesuai dengan target yang diharapkan.

\section{HASIL PENELITIAN DAN PEMBAHASAN}

Hasil penelitian kelas ini diperoleh dari tindakan prasiklus, siklus I, dan siklus II. Hasil tes prasiklus berupa tes tertulis tentang penguasaan menulis karangan sederhana sebelum diberi tindakan dengan menggunakan media gambar berseri Hasil tes tindakan pada siklus I, dan siklus II berupa penguasaan menulis karangan sederhana dengan media gambar berseri. Data tersebut diperoleh melalui instrumen nontes, yaitu observasi, catatan harian guru, dan dokumentasi foto.

Sebagai alternatif pemecahan masalah terhadap rendahnya penguasaan menulis karangan sederhana siswa tunarungu, upaya yang dilakukan peneliti pada kondisi awal sebelum dilakukannya dengan media gamabar berseri . Namun upaya ini masih kurang optimal meningkatkan penguasaan menulis karangan untuk siswa tunarungu. Sebagaimana hasil tes sebelum tindakan dilakukan. Sebelum pelaksanaan tindakan dilaksanakan, kondisi awal penguasaan menulis karangan sederhana berdasarkan hasil pretes dapat dilihat pada tabel di bawah ini.

Tabel Perolehan nilai Prasiklus (Pretest)

\begin{tabular}{|c|c|c|c|c|c|c|c|c|c|c|c|c|c|c|c|}
\hline \multirow[b]{2}{*}{ No. } & \multirow{2}{*}{$\begin{array}{l}\text { Nama } \\
\text { Siswa }\end{array}$} & \multicolumn{10}{|c|}{ Indikator } & \multirow[b]{2}{*}{ Nilai } & \multirow[b]{2}{*}{ KKM } & \multicolumn{2}{|c|}{ Kriteria Nilai } \\
\hline & & 1 & 2 & 3 & 4 & 5 & 6 & 7 & 8 & 9 & 10 & & & Tuntas & $\begin{array}{c}\text { Tidak } \\
\text { Tuntas }\end{array}$ \\
\hline 1 & WRN & 1 & 0 & 0 & 1 & 1 & 0 & 0 & 0 & 0 & 1 & 40 & 60 & & $\mathrm{X}$ \\
\hline 2 & FF & 1 & 1 & 1 & 0 & 1 & 0 & 1 & 1 & 0 & 0 & 60 & 60 & V & \\
\hline 3 & MP & 1 & 1 & 1 & 0 & 0 & 0 & 1 & 0 & 0 & 0 & 40 & 60 & & $X$ \\
\hline 4 & MR & 1 & 1 & 1 & 0 & 0 & 1 & 0 & 1 & 0 & 0 & 50 & 60 & & $\mathrm{X}$ \\
\hline 5. & NA & 1 & 1 & 1 & 0 & 0 & 1 & 0 & 1 & 0 & 0 & 50 & 60 & & $X$ \\
\hline
\end{tabular}

Keterangan :

$\mathrm{v}:$ Tuntas

$\mathrm{x}$ : Tidak tuntas

Tabel di atas adalah perolehan nilai yang dilakukan sebelum dilaksanakan tindakan, instrumen pengukuran penilaiannya diambil dari indikator kinerja keberhasilan yang telah ditentukan. Dari hasil pretes ada empat siswa yang nilainya termasuk kategori kurang, 
yaitu 40 dan 50 untuk itu peneliti mengambil langkah untuk meningkatkan nilai pada mata pelajaran B.Indonesia khususnya menulis karangan sederhana untuk mencapai kriteria ketuntasan minimal melalui media gambar berseri. Tabel di atas jika dibuat grafik adalah sebagai berikut.

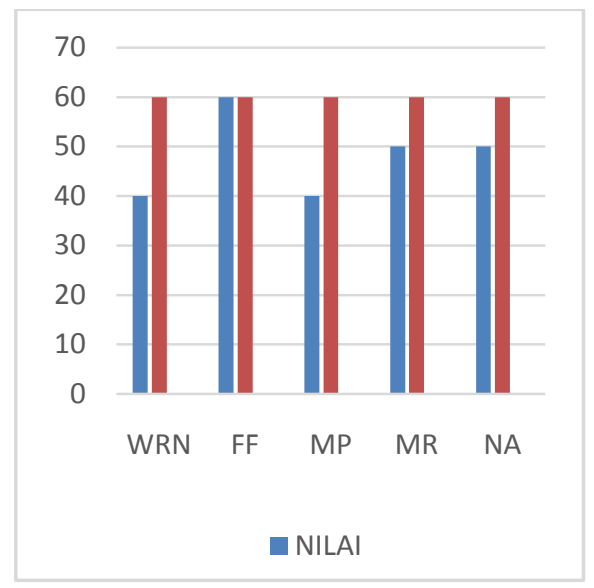

\section{Grafik Nilai Awal sebelum Pelaksanaan Siklus I}

\begin{abstract}
Pada bagian siklus I akan dibahas mengenai proses pembelajaran menulis karangan sederhana dan perilaku siswa setelah mengikuti pembelajaran dengan penerapan media gambar berseri. Proses pembelajaran, yaitu proses penerapan gambar berseri untuk penguasaan menulis karangan sederhana.
\end{abstract}

Berdasarkan hasil observasi terhadap proses pembelajaran dan prestasi belajar sebelumnya dapat dijadikan sebagai data awal untuk melaksanakan tindakan. Pelaksanaan kegiatan pada siklus I meliputi perencanaan, pelaksanaan, pengamatan, dan refleksi. Pada siklus ini dilaksanakan 2 kali pertemuan ( 2 X 30 menit) yaitu pada hari selasa tanggal 7 Agustus, dan rabu 8 Agustus. Tahapan-tahapan yang dilaksanakan pada siklus I adalah sebagai berikut.

Pertemuan pertama pada hari selasa tanggal 7 Agustus. Pada kegiatan awal, guru memulainya dengan salam, berdoa, mengecek kehadiran siswa. melaksanakan apersepsi, serta orientasi mengenai hal yang harus dicapai siswa setelah pembelajaran usai. Guru juga memberikan motivasi berupa permainan ringan, ataupun pemberian nasihat-nasihat.

Setelah kegiatan awal, selanjutnya adalah kegiatan inti eksplorasi. Pada kegiatan ini, dilaksanakan pembelajaran menggunakan gambar berseri dalam menulis karangan sederhana. Langkah menulis karangan dengan menggunakan gambar berseri meliputi 3 tahapan, yaitu (1) gambar berseri di tempelkan di papan tulis. (2) guru menyuruh siswa mengurutkan gambar berseri tersebut sesuai nomornya. (3) siswa disuruh menulis karangan sederhana berdasarkan gambar berseri sesuai urutan gambar yang ditentukan.

Kegiatan inti selanjutnya, yaitu elaborasi. Pada tahap ini semua siswa siap dengan alat tulis dan bukunya, dimulai dengan mengurutkan gambar berseri yang ditentukan kemudian siswa disuruh menulis karangan sederhana.

Jika siswa ada yang tidak mampu melakukannya maka di ulang 
kembali sampai siswa itu mampu menulis karangan sederhana.

$$
\text { Kegiatan inti, tahap }
$$

konfirmasi, kegiatan yang dilakukan meliputi penyampaian hasil sharingoleh guru pelaksanaan evaluasi praktik dan tertulis, serta pemberian reward kepada siswa yang menulis karangan sederhana yang bagus.

Kegiatan akhir, pembelajaran diisi dengan menyimpulkan materi, mencatat materi, menanyakan halhal yang belum dipahami siswa. Pembelajaran diakhiri dengan berdoa dan salam. Kegiatan observasi bertujuan untuk mengevaluasi rangkaian pembelajaran yang telah dilaksanakan, sebagai acuan dalam melaksanakan pembelajaran selanjutnya. Hal-hal yang diamati adalah kegiatan yang dilakukan oleh guru dan siswa, serta hasil belajar siswa.

Pertemuan kedua pada hari selasa tanggal 14 Agustus 2014 dilakukan dengan a) mengurutkan gambar berseri b) menempelkan di papan tulis sesuai urutan gambar d) menuliskan karangan sederhana sesuai urutan gambar.

Adapun kegiatan siswa pada siklus I dapat dilihat pada gambar berikut ini. Hasil belajar siswa siklus I dapat digambarkan dalam tabel sebagai berikut.

Tabel Perolehan Nilai Menulis Karangan pada Siklus I

\begin{tabular}{|l|l|l|l|l|l|l|l|l|l|l|l|l|l|l|l|c|}
\hline \multirow{2}{*}{ No. } & \multirow{2}{*}{$\begin{array}{l}\text { Nama } \\
\text { Siswa }\end{array}$} & $\mathbf{1}$ & $\mathbf{2}$ & $\mathbf{3}$ & $\mathbf{4}$ & $\mathbf{5}$ & $\mathbf{6}$ & $\mathbf{7}$ & $\mathbf{8}$ & $\mathbf{9}$ & $\mathbf{1 0}$ & Nilai & \multirow{2}{*}{ KKM } & \multicolumn{2}{|c|}{ Kriteria Nilai } \\
\hline 1 & WRN & 1 & 0 & 0 & 1 & 1 & 0 & 0 & 1 & 0 & 1 & 50 & 60 & & $\begin{array}{c}\text { Tidak } \\
\text { Tuntas }\end{array}$ \\
2 & FF & 1 & 1 & 1 & 0 & 1 & 0 & 1 & 1 & 0 & 0 & 60 & 60 & $\mathrm{~V}$ & \\
3 & MP & 1 & 1 & 1 & 0 & 0 & 0 & 1 & 0 & 0 & 0 & 40 & 60 & & $\mathrm{X}$ \\
4 & MR & 1 & 1 & 1 & 0 & 0 & 1 & 0 & 1 & 0 & 0 & 50 & 60 & & $\mathrm{X}$ \\
5. & NA & 1 & 1 & 1 & 0 & 0 & 1 & 0 & 1 & 0 & 0 & 50 & 60 & & $\mathrm{X}$ \\
\hline
\end{tabular}

Keterangan :

$\mathrm{V}:$ Tuntas

$\mathrm{X}$ : Tidak Tuntas

Tabel di atas dapat dijelaskan bahwa dari keempat subyek 1 orang mendapat nilai 60,3 orang 50, dan 1 orang mendapat nilai 40. Dari tabel tersebut dapat disimpulkan bahwa siswa setelah diberi pengajaran dengan penggunaan media gambar berseri ternyata belum ada peningkatan yang begitu signifikan dalam menulis karangan sederhana. 


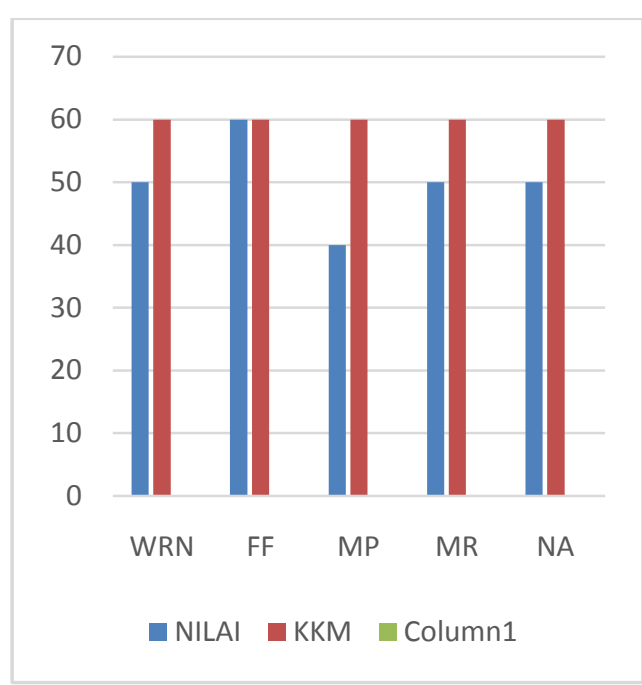

\section{Grafik Nilai Awal Sebelum Pelaksanaan Siklus I}

Berdasarkan hasil tes dan pengamatan pelaksanaan siklus I dengan teman sejawat diperoleh gambaran refleksi sebagai berikut:

\section{Kelebihan}

a. Aktivitas permainan yang dilakukan guru berhasil memotivasi siswa untuk bisa bersemangat pada pembelajaran.

b. Jika dibandingkan dengan kondisi awal, gambar berseri berhasil mengatasi rasa bosan siswa pada pembelajaran B.Indonesia pada aspek menulis karangan sederhana karena dilakukan dengan media yang menyenagkan siswa.

\section{Kelemahan}

a. Berdasarkan perolehan nilai baik secara individu maupun secara klasikal ada 4 (tiga) siswa yang belum dapat mencapai nilai ketuntasan (KKM) pada nilai pelajaran B.Indonesia yang sudah ditentukan, yaitu 60 .

b. Berdasarkan hasil pengamatan tentang aktivitas siswa, ada dua orang siswa kurang dalam partisipasi, kreativitas dan inisiatif.

Berdasarkan perolehan nilai serta presentase peningkatan belum sesuai yang diharapkan peneliti, peneliti merasa perlu untuk mengambil langkah selanjutnya dengan mengadakan tindakan siklus II.

Pembelajaran pada siklus ini merupakan kelanjutan dari pembelajaran sebelumnya. Tahap pelaksanaan tindakan pasa siklus II ini menggunakan perencanaan pembelajaran yang diperbaiki oleh guru berdasarkan refleksi pada siklus I. Pada siklus ini dilaksanakan 2 kali pertemuan ( 2 X 30 menit) yaitu pada hari selasa tanggal 14 September 2016, rabu 15 september 2016.

Dalam tahap pelaksanaan tindakan ini adalah melaksanakan kegiatan tindakan, yaitu melakukan proses belajar mengajar berdasarkan bahan/materi yang telah disusun dan didasarkan pada metode serta alat media yang dipersiapkan. Alat yang dipersiapkan dalam penelitian ini adalah kartu gambar berseri.

Pada tahap pendahuluan pada pertemuan pertama pada hari selasa tanggal 14 September 2016, guru memberi salam, mengajak siswa untuk berdoa dan mengecek kehadiran siswa. Guru menyiapkan peserta didik untuk mengikuti 
Sitti Nurliani Tarigan : Meningkatkan Keter ....

kegiatan pembelajaran dan menyampaikan tujuan pembelajaran.

Adapun kegiatan inti pada pertemuan pertama adalah a) pembelajaran dimulai dengan menyusun gambar berseri di tempelkan di papan tulis b) kartu gambar berseri di urutkan sesuai nomor yang ada; c) siswa mengamati gambar dan menelaah isi gambar d) setelah mengerti apa isi gambar berseri tersebuut siswa mulai

menulis karangan sederhana sesuai urutan gambar yang ada.

Pertemuan kedua pada hari Sabtu tanggal 21 September 2016 dilakukan dengan sama dengan pertemuan pertama hanya saja pada pertemuan keduaini siswa di berikan ter tertulis dan waktu diperpanjang dari pertemuan I.

Hasil belajar siswa siklus II dapat digambarkan dalam tabel di bawah ini sebagai berikut:

Tabel Perolehan Nilai pada Siklus II

\begin{tabular}{|c|c|c|c|c|c|c|c|c|c|c|c|c|c|c|c|}
\hline \multirow[b]{2}{*}{ No } & \multirow{2}{*}{$\begin{array}{l}\text { Nama } \\
\text { Siswa }\end{array}$} & \multicolumn{10}{|c|}{ Indikator } & \multirow[b]{2}{*}{ Nilai } & \multirow[b]{2}{*}{ KKM } & \multicolumn{2}{|c|}{ Kriteria Nilai } \\
\hline & & 1 & 2 & 3 & 4 & 5 & 6 & 7 & 8 & 9 & 10 & & & Tuntas & $\begin{array}{c}\text { Tidak } \\
\text { Tuntas }\end{array}$ \\
\hline 1 & WRN & 1 & 1 & 0 & 1 & 1 & 0 & 0 & 1 & 0 & 1 & 60 & 60 & $\mathrm{~V}$ & \\
\hline 2 & FF & 1 & 1 & 1 & 1 & 1 & 0 & 1 & 1 & 0 & 0 & 70 & 60 & $\mathrm{v}$ & \\
\hline 3 & MP & 1 & 1 & 1 & 0 & 0 & 0 & 1 & 1 & 0 & 0 & 50 & 60 & & $\mathrm{x}$ \\
\hline 4 & MR & 1 & 1 & 1 & 0 & 1 & 1 & 0 & 1 & 0 & 0 & 60 & 60 & $\mathrm{v}$ & \\
\hline 5 & NA & 1 & 1 & 1 & 0 & 1 & 1 & 0 & 1 & 0 & 0 & 60 & 60 & & \\
\hline
\end{tabular}

Keterangan :

$\mathrm{V}:$ Tuntas

$\mathrm{X}$ : Tidak tuntas

Dari tabel di atas dapat dijelaskan bahwa dari keempat subjek: 1 orang mendapat nilai 70,3 orang 60 dan 1 orang mendapat nilai 50. Dari tabel tersebut dapat disimpulkan bahwa siswa setelah diberi pengajaran dengan media gambar berseri ternyata sudah ada peningkatan yang begitu signifikan dalam penguasaan menulis karangan sederhana.

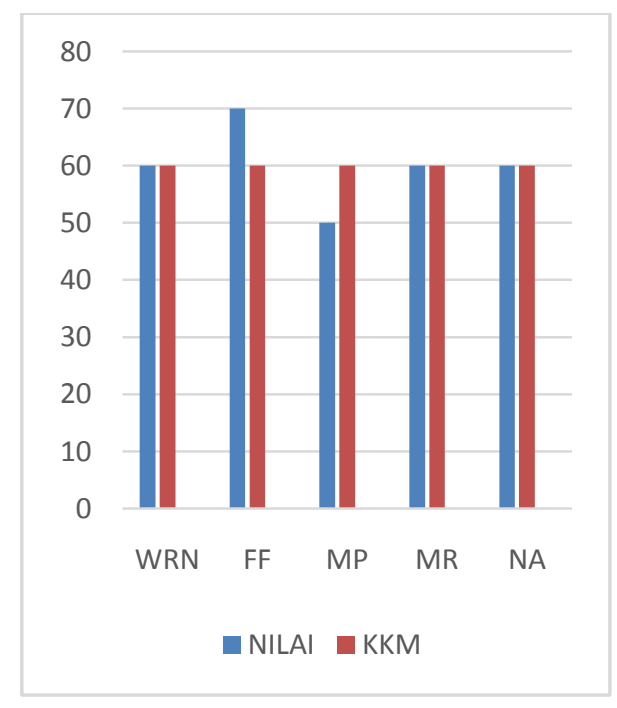

Grafik Nilai Hasil Tes Siklus II 
Berdasarkan hasil tes dan pengamatan pelaksanaan siklus II dengan teman sejawat diperoleh gambaran refleksi sebagai berikut:

\section{Kelebihan}

a. Siswa terlihat aktif dalam kegiatan pembelajaran sehingga pembelajaran terpusat pada siswa. Peran guru masih sebagai pembimbing.

b. Siswa semakin antusias mengikuti pembelajaran dengan mnggunakan gambar berseri sebagai media pembelajaran.

\section{Kekurangan}

a. Berdasarkan perolehan nilai, baik secara individu maupun secara klasikal ada 1 (satu) siswa yang belum dapat mencapai nilai ketuntasan (KKM) pada nilai pelajaran B.Indonesia yang sudah ditentukan, yaitu 60;

b. Berdasarkan hasil pengamatan tentang aktivitas siswa, ada 1 siswa kurang dalam partisipasi, kreativitas, dan inisiatif.

c. Berdasarkan perolehan nilai serta prosentasenya peningkatan sudah memenuhi target yang diharapkan peneliti, peneliti menghentikan penelitian karna target sudah tercapai memenuhi $70 \%$ siswa yang berhasil.

\section{Pembahasan}

Setelah pelaksanaan tindakan pada siklus I, dan II hasil secara keseluruhan dapat dilaporkan dalam tabel dan grafik yang menunjukkan peningkatan dalam perolehan skor dan nilai, baik secara individu maupun secara klasikal. Dengan demikian, dapat diperoleh jawaban seperti pada hipotesis tindakan bahwa penggunaan media gambar berseri dapat meningkatkan keterampilan menulis karangan sederhana pada siswa tunarungu kelas D-IV-B SLB-E Negeri Pembina Medan Tahun Pelajaran 2016/2017. Peningkatan perolehan nilai dapat digambarkan pada tabel 13 dan grafik berikut.

Tabel Data Peningkatan Nilai

Penguasaan Kosakata Kelas I Tunarungu pada Siklus I, dan II

\begin{tabular}{|c|c|c|c|}
\hline $\begin{array}{c}\text { Nama } \\
\text { Anak }\end{array}$ & $\begin{array}{c}\text { Nilai } \\
\text { Awal }\end{array}$ & $\begin{array}{c}\text { Nilai Siklus } \\
\text { I }\end{array}$ & $\begin{array}{c}\text { Nilai } \\
\text { Siklus } \\
\text { II }\end{array}$ \\
\hline WRN & 40 & 50 & 60 \\
\hline FF & 60 & 60 & 70 \\
\hline MP & 40 & 40 & 50 \\
\hline $\begin{array}{l}\text { MR } \\
\text { NA }\end{array}$ & 50 & 50 & 60 \\
\hline $\begin{array}{l}\text { Rata- } \\
\text { rata }\end{array}$ & 48 & 50 & 60 \\
\hline
\end{tabular}

Tabel di atas menggambarkan rekapitulasi peningkatan berdasarkan skor dan nilai, pada tabel 13 tersebut menggambarkan adanya peningkatan yang dianggap cukup oleh peneliti. Hal ini karena peningkatan tersebut sudah menunjukkan adanya keberhasilan dalam penelitian karena pada tiap-tiap siklus telah menunjukkan peningkatan baik secara individu maupun klasikal. 


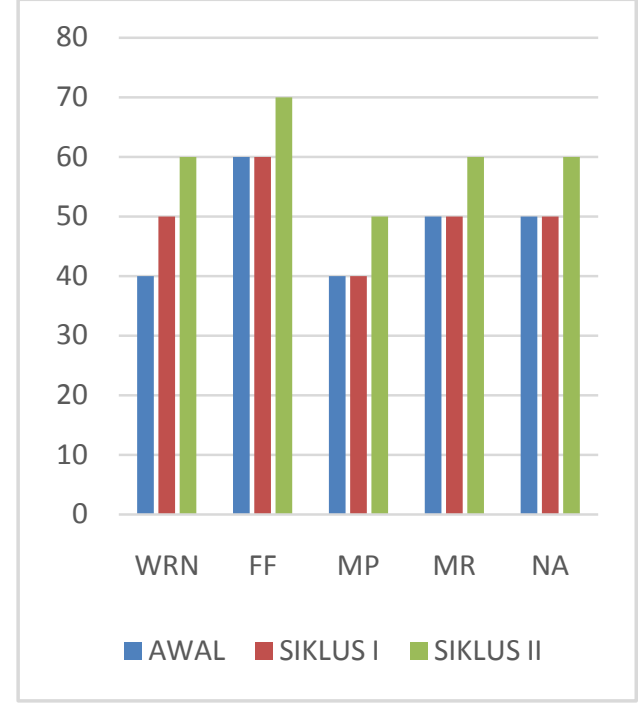

\section{Grafik Hasil Belajar Keterampilan Menulis Karangan Sederhana Pra siklus, Siklus I, dan II}

\section{SIMPULAN}

Setelah dilakukan pengamatan dan analisis dalam penelitian diperoleh beberapa kesimpulan antara lain :

a. Penggunaan gambar berseri dalam pembelajarn menulis karanagn sederhana pada siswa tunaryngu pada kelas D-IV-B SLB Negeri Pembina Medan mengalami peningkatan ke arah yang lebih baik, dan dapat meningkatkan motivasi anak untuk belajar di dalam kelas. Hal ini dapat dilihat dari tiga indikator yaitu: (1). Menyebutkan urutan gambar berseri dengan benar (2). Mengurutkan gambar berseri secara berurutan sesuai gambar (3). Dapat menulis karangan sederhana sesuai gambar berseri yang di berikan guru. b. Setelah menggunakan gambar berseri dalam pembelajarn B.Indonesia keterampilan menulis karangan sederhana dapat ditingkatkan dimana pada pra observasi sebelum menngunakan gambar berseri hanya 1 orang siswa yang paham bagaimana cara menulis karangn sederhana, kemudian dilanjutkan ke siklus I siswa semakin termotivasi untuk menulis karangn sederhana setelah di berikan gambar berseri sebagai media. Selanjutnya pada siklus ke II hanya satu orang siswa yang tidak mencapai KKM yang sudah ditentukan dengan demikian gambar berseri dapat meningkatkan keterampilan menulis karangan sederhana bagi siswa tunarungu di kelas DIV-B SLB-E Negeri Pembina Medan.

\section{DAFTAR RUJUKAN}

Edja, Sadjaah. 2005. Pendidikan Bahasa Bagi Anak gangguan Pendengaran dalam Keluarga. Jakarta: Depdiknas Dirjend, Pend. Tinggi Direktorat Pembinaan Pend. Tenaga Kependidikan dan Ketenagaan Perguruan Tinggi.

Maria, Susila Yuwati. 2010. Penguasaan Bahasa Anak Tunarungu, Jakarta : Yayasan Santi Rama.

Mufti, Salim. 2014. Pendidikan anak Tunarungu, Jakarta : Depdikbud 
Mustakim. 2014. Membina Kemampuan Berbahasa. Jakarta: Gramedia Utama

Permanarian Somat \& Tati Herawati. 2004. Ortopedagogik Anak Tunarungu, Departemen Pendidikan Dan Kebudayaan Direktorat Jendral Pendidikan Tinggi. Jakarta: Proyek Pendidikan Tenaga Guru.

Rachmad, Djatun. 2007. Metode Maternal Reflektif. Surakarta: Penelitian Dikti Hibah Bersaing.

Sam Isbani. 1987. Komunikasi Anak

Tunarungu Wicara . Jakarta : Depdikbud

Sarjono. 2005. Terapi Wicara.

Jakarta : Depdiknas Dirjend.
Pend.Tinggi.Direktorat

Pembinaan Pend. Tenaga

Kependidikan dan Ketenagaan Perguruan Tinggi

Sarwiji Suwandi dan Madya Eko Susilo. 2007. Penelitian Tindakan Kelas dan Penulisan Karya Ilmiah. Modul pendidikan dan Latihan Profesi Guru, Rayon 13 Surakarta.

Soedjito. 1992. Kalimat Efektif. Bandung : CV. Remaja Karya.

Sunarto. 2005. Percakapan dalam MMR. Jawa Tengah : Dinas $\mathrm{P}$ dan K Unit PLB.

Totok Bintoro. 2008. Materi, Metode dan Penilaian Bina Komunikasi Persepsi Bunnyi dan Irama (BKPBI). 